\title{
Do Crude Oil Price Changes Affect Economic Welfare? Empirical Evidence from Ghana*
}

\author{
${ }^{1}$ K. Kamasa, ${ }^{2}$ D. B. Amponsah, ${ }^{2}$ P. Forson \\ ${ }^{1}$ University of Mines and Technology, Tarkwa, Ghana \\ ${ }^{2}$ Kwame Nkrumah University of Science and Technology, Kumasi, Ghana
}

Kamasa, K., Amponsah B. D., and Forson, P. (2020), "Do Crude Oil Price Changes Affect Economic Welfare? Empirical Evidence from Ghana", Ghana Mining Journal, Vol. 20, No. 1, pp. 51 - 58.

\begin{abstract}
This paper sought to explore the impact of crude oil price changes on economic welfare in Ghana. The paper employed the Autoregressive distributed lag (ARDL) estimation technique on an annual time series data spanning $1983-2017$. The findings revealed that crude oil price changes have a negative and significant impact on economic welfare in the short and long run, albeit marginal. In terms of covariates, the findings revealed that trade openness and gross fixed capital formation have positive and significant impact whilst interest rate have negative impact on economic welfare in both the short and long run. Foreign direct investment had a positive effect, albeit insignificant. The paper recommends among others, the hedging of prices with respect to imported crude oil so as to manage the risks associated with crude oil price changes on economic welfare.
\end{abstract}

Keywords: Economic Welfare, Crude Oil Prices Changes, Autoregressive Distributed Lag, Ghana

\section{Introduction}

In recent times, crude oil is acknowledged as an extremely important component in terms of energy resource, which plays an invaluable role in the manufacture of any product and service required to drive economic growth and consequently economic welfare. Consequently, changes in the prices of crude oil are inevitable and have been known to significantly account for variations in the prices of goods and services on which economic welfare depends. As noted by Awunyo-Vitor et al., (2018), changes in crude oil price has the possibility to affect economic growth and welfare.

As at 2010, Ghana's share of primary fuel production by estimation composed of $80 \%$ biomass, $5 \%$ crude oil and $15 \%$ hydro energy. However, in 2017, the statistics was estimated at $28 \%$ biomass, $62 \%$ crude oil, $4 \%$ hydro energy and $6 \%$ natural gas (Anon, 2018). Crude oil is therefore recognised as a key energy resource that drives the greater proportion of the profitable sectors of the economy. To that respect, it can be argued that the economy of Ghana is susceptible to the changes in crude oil prices. According to Anon (2014), fluctuations in crude oil prices as well as crude oil availability have a significant effect on the economy of Ghana. Moreover, crude oil price appreciation raises the prices of equity market shares that adversely affect the income of investors which lead to financial market instability (Bouri, 2015). Thus, crude oil price changes directly affect consumer purchasing power in an economy, occasioned by proportionate changes in prices of domestic petroleum products.
On the one hand, economic welfare constitutes satisfaction of needs such as food, shelter and healthcare. It is a fact that income levels hugely determine the quantity of these needs available to a household for consumption. Since individual households seek to maximize their utility, utility can be equated to household welfare at the economy-wide level (Glewwe, 1991). Neoclassical economists are of the view that the ultimate purpose of all economic activities is consumption. It therefore links the overall success of an economy's productivity to consumption per capita. Given that prices of goods and services are influenced significantly by the fluctuations in the prices of imported petroleum products, the presence of substantial variations in the petroleum prices greatly influence personal consumption expenditures (see Wang, 2013) and to an extent affects economic welfare.

The crude oil price - economic growth relationship has received quite an attention. Al Sabah et al., (2016) examined how living standards could be sustained amidst volatile oil prices using Kuwait as a key representative of the oil exporting Gulf countries. A positive relationship between GDP (the proxy for living standards) and crude oil price increases as well as investment growth were obtained. Sanchez (2011) assessed the influence of appreciating crude oil prices on welfare in countries that import crude oil. The findings revealed that oil prxice appreciation has a negative impact on GDP with mean yearly losses in GDP fluctuating from $0.1 \%$ to $20 \%$ for Tanzania and Kenya respectively. On their part, Olukayode et al., (2018) employed the ARDL in modeling the effect of petroleum price on human welfare in Nigeria and found evidence that the appreciation of 
petroleum prices has a negative effect on human welfare. With respect to Ghana, Cantah and Asmah (2015) re-examined the interrelation existing between crude oil price and economic growth using the ARDL estimator. The results indicated that appreciation in crude oil price had a negative influence on Ghana's economic growth in both the short and long-run with reinforcement from upsurges in government spending as a mitigating reaction to crude oil price variations in the form of fuel subsidies.

Aside the limited studies that have been undertaken in the case of Ghana, nearly all the related studies focused on economic growth as a measure of welfare (see for instance Cantah \& Asmah, 2015). However, the quality of life (welfare) as an economic model comprises intrinsic personal factors such as literacy rates, life expectancy and poverty rates which are non-existent in economic growth. Furthermore, the few studies examined focused on crude oil prices and failed to provide adequate consideration for changes in the crude oil prices, which has more notable impact on growth according to the renaissance growth theory. This paper thus enriches the literature by estimating the effect of crude oil price changes on economic welfare in Ghana.

The rest of the paper is structured as follows. Section 2 presents the methodology employed for the paper, which consists of model specification, estimation technique, data and descriptive statistics. Section 3 discusses the empirical results and findings while section 4 concludes the paper with policy implications and recommendations.

\section{Resources and Methods Used}

\subsection{Model Specification}

The endogenous growth model presents a suitable framework that throws more light on the interaction between changes in crude oil prices and economic welfare. Following other studies on crude oil price changes and economic welfare such as Dogah (2015), Olukayode et al., (2018) and AwunyoVitor et al., (2018), the empirical model for this paper is given as Equation (1):

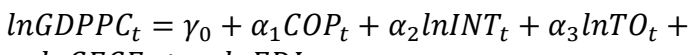

$\alpha_{4} \ln G F C F_{t}+\alpha_{5} \ln F D I_{t} \varepsilon_{t}$

where $\ln G D P P C_{t}$ is $\log$ of GDP per capita (proxy for economic welfare), $C O P_{t}$ is changes in crude oil


trade openness, $\ln G F C F_{t}$, and $\ln F D I_{t}$ are the $\log$ of gross fixed capital formation and foreign direct investment respectively. Finally, $\varepsilon_{t}$ is the error term.

\subsection{Estimation Strategy}

The application of the Ordinary Least Square (OLS) method to estimate the model specified in Equation (1) requires that the variables in the model should be stationary without the presence of unit roots. If unit root is present, differencing of the variables aimed at achieving stationarity for all the variables and subsequent application of the OLS method may seem to be a feasible way to estimate the model specified. However, the differenced series constitutes only the short-run change in the time series to the exclusion of the long-run information, which is a key requirement for analyses. This problem is avoided by employing the Autoregressive Distributed Lag (ARDL) estimator ahead of other cointegration methods in the estimation of the long-run equilibrium inferred by Equation (1).

ARDL models are known to produce accurate results in testing for long-run associations in smaller samples. In addition, the application of ARDL is appropriate even in the presence of a mixture of different orders of integration $(\mathrm{I}(0)$ and I(1) series). A dynamic error correction model (ECM) can be derived from ARDL. Similarly, the ECM integrates the short-run dynamics with the long-run equilibrium without losing long-run information and avoids problems such as spurious relationship resulting from non-stationary time series data.

An ARDL model may be written as shown in Equation (2):

$y_{t}=\alpha+\sum_{i=1}^{\rho} \gamma_{i} y_{t-1}+\sum_{j=1}^{k} \sum_{i=0}^{q_{j}} X_{j, t-i^{\prime}} \beta_{j, i}+\varepsilon_{t}$

where $\rho$ is the number of lags of the dependent variable, $y_{t}, q_{1}$ is the number of lags of the first explanatory variable, $X_{1}$ and $q_{k}$ is the number of lags of the $k$-th explanatory variable, $X_{k}$.

To specify an ARDL model, one must determine how many lags of each variable should be included. Since ARDL model can be estimated via least squares regression, standard Akaike was used for model selection. Since an ARDL model estimates the dynamic relationship between a dependent variable and explanatory variables, it is possible to transform the model into a long-run representation, showing the long run response of the dependent variable to a change in the explanatory variables. The estimated long-run coefficients is shown in Equation (3):

$$
\theta_{j}=\frac{\sum_{i=1}^{x j} \widehat{\beta_{\jmath, l}}}{1-\sum_{i=1}^{\rho} \gamma_{i}}
$$


The cointegrating regression form of the ARDL model is obtained by transforming Equation (2) into differences and substituting the long-run coefficients from Equation (3). This is shown in Equation (4):

$$
\begin{aligned}
\Delta y_{t} & = \\
& -\sum_{i=1}^{\rho-1} \gamma_{i^{*}} \Delta y_{t-1}+ \\
& \sum_{j=1}^{k} \sum_{i=0}^{q_{j-1}} \Delta X_{j, t-i^{\prime}} \beta_{j, i^{*}}-\widehat{\emptyset} E C T_{t-1}+\varepsilon_{t}
\end{aligned}
$$

where

$$
\begin{gathered}
E C T_{t}=y_{t}-\alpha-\sum_{j=1} X_{j, t} \widehat{\theta}_{J} \\
\widehat{\emptyset}=1-\sum_{i=1}^{\rho} \widehat{\gamma_{l}} \\
\gamma_{i^{*}}=\sum_{m=i+1}^{\gamma_{m}} \\
\beta_{j, i^{*}}=\sum_{j} \beta_{j, m}
\end{gathered}
$$

On the premise of the existence of a distinct longrun relationship among the variables under study, the estimable model can be expressed in Equation (5) as:

$$
\begin{aligned}
& \ln G D P P C_{t}=\gamma_{0}+\sigma_{1} \ln G D P P C_{t-1}+\sigma_{2} C O P_{t-1}+ \\
& \sigma_{3} \operatorname{lnINT}_{t-1}+\sigma_{4} \ln T O_{t-1}+\sigma_{5} \operatorname{lnGFCF}_{t-1}+ \\
& \sigma_{6} \ln F D I_{t-1}+\sum_{i=1}^{q} \beta_{1 i} \Delta \ln G D P P P C_{t-i}+
\end{aligned}
$$

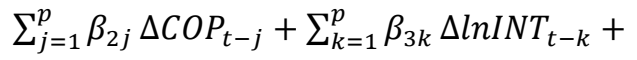

$$
\begin{aligned}
& \sum_{l=1}^{p} \beta_{4 l} \Delta \ln T O_{t-l}+\sum_{m=1}^{p} \beta_{5 m} \Delta \ln G F C F_{t-m}+ \\
& \sum_{q=1}^{p} \beta_{6 q} \Delta \ln F D I_{t-q}+\tau E C T_{t-1}+\varepsilon_{t}
\end{aligned}
$$

where $\gamma_{0}, \sigma_{1, \ldots 6}, \beta_{1, \ldots 6}, E C T_{t-1}, \tau$ and $\varepsilon_{t}$ are the intercept, the long-run multipliers, short-run multipliers, lagged error correction term in the ECM, the coefficient of the error correction term and the stochastic term respectively.

\subsection{Data Sources}

The paper employed annual times series data for the period 1983 to 2017 for its analysis. The sources of data were the World Bank's World Development Indicators, The Bank of Ghana and Organisation of Petroleum Exporting Countries (OPEC) crude oil price database.

\subsection{Definition of Variables}

Crude oil price changes (COP) is the annual rate of changes in crude oil price expressed as a percentage of the previous year's price as shown below:

$$
\frac{O i l_{t}-O i l_{t-1}}{O i l_{t-1}} \times 100
$$

where $O i l_{t}$ is the current year's crude oil price and $O i l_{t-1}$ refers to previous year's crude oil price.

GDP per capita (GDPPC) is gross domestic product divided by midyear population. It is the measure of the economic output of a country which considers the total number of citizens in the country within a specific period, which determines how citizens feel about a country's prosperity

Interest rate (INT) is the percentage of principal demanded by a lender for the use of their money.

Trade openness (TO) is a measure of liberalisation and represents the sum of exports and imports of goods and services calculated as a ratio to gross domestic product.

Foreign direct investment (FDI) is the net inflows of investment made by an entity/company in one country (source) with controlling ownership of a business in another country (host)

Gross fixed capital formation (GFCF) is a measure of gross net investment (acquisitions minus disposals) in fixed capital assets by enterprises, government and households within the domestic economy, during an accounting period such as a quarter or a year.

\subsection{Descriptive Statistics of Variables}

In terms of descriptive statistics, the log of GDP per capita has a mean of 6.41, standard deviation of 0.71 and is normally distributed with Jarque-Bera statistic of 4.96 (p-value of 0.08). Crude oil price changes (COP) has a mean of 5.42, standard deviation of 26.67 and is normally distributed with Jarque-Bera statistic of 0.73 (p-value of 0.69). Log of interest rate has a mean of 3.43, standard deviation of 0.23 and is normally distributed with Jarque-Bera statistic of 1.12 (p-value of 0.57 ). Additionally, log of trade openness, log of gross fixed capital formation and $\log$ of foreign direct investment are described by means of 22.70, 21.33 and 18.86 respectively and corresponding standard deviations of $1.27,1.30$ and 2.43 respectively. These variables were are all normally distributed. 


\section{Results and Discussion}

\subsection{Unit Roots Results}

The results of the ADF and PP tests for unit root with intercept and trend at both the levels and first difference are presented in Table 1. It reveals that COP is integrated of order 0 , whiles $\ln$ GDPPC, $\ln \mathrm{INT}, \ln \mathrm{TO}, \ln \mathrm{FDI}$ and $\ln \mathrm{GFCF}$ are integrated of order 1. This finding supports the preferential selection of the ARDL technique for the estimation given the mixture of orders of integration.

\subsection{ARDL Bounds Test for Cointegration Results}

Table 2 showed that there exists cointegration among the variables because the F-Statistic of 7.227 was higher than the upper bound at $10 \%$ (3.79), 5\% (4.25) and $1 \%$ (5.23). This portends that the variables are cointegrated and that there exists a long-run relationship between GDP per capita and the explanatory variables.

\subsection{Long-Run Effect of Crude Oil Price Changes on Economic Welfare}

Results from the ARDL estimator as displayed in Table 3 showed that a negative and significant relationship exists between crude oil price changes and economic welfare. That is, a $1 \%$ upward change in crude oil price reduces GDP per capita by $0.0032 \%$ ceteris paribus, which by inference means that upward changes in crude oil price has a negative marginal influence on economic welfare in Ghana. The result is supported by the Renaissance growth theory, which postulates that crude oil price changes have a negative effect on the growth of the economy. From the supply side, crude oil is a fundamental input in the production function, and consequently an increase in its price lead to higher production costs, low productivity and consequently lower income. From the demand side, crude oil price increase leads to lower consumption through its positive association with disposable income. The combined effect from the demand and supply side means that an upward crude oil price change leads to lower economic welfare. The paper's findings agrees with Dogah (2015) who recognised a negative and significant impact of crude oil price shocks on GDP per capita in Ghana as well as Olukayode et al., (2018) who found a negative relationship between crude oil price changes and human welfare in Nigeria.

As far the covariates are concerned, findings from the results revealed a negative and significant effect of interest rate on economic welfare. Thus, a $1 \%$ appreciation in interest rate leads to a decrease in GDP per capita by $1.039 \%$ ceteris paribus. The outcome of the study falls in line with the loanable funds theory, which posits that an increase in interest rate is associated with an increase in the cost of borrowing by firms to expand productive activities. This ends up in a reduction in investment and growth, which affect economic welfare eventually. This result is in line with studies such as Fiadzo et al., (2016), Arhin et al., (2016) and Ajayi et al., (2017).

Table 1 Results of Unit Root Tests

\begin{tabular}{|c|c|c|c|c|c|c|c|c|}
\hline \multirow{3}{*}{ Variable } & \multicolumn{4}{|c|}{ Level } & \multicolumn{4}{|c|}{ First Difference } \\
\hline & \multicolumn{2}{|c|}{ ADF } & \multicolumn{2}{|c|}{ PP } & \multicolumn{2}{|c|}{ ADF } & \multicolumn{2}{|c|}{ PP } \\
\hline & Constant & $\begin{array}{l}\text { Constant } \\
+ \text { trend }\end{array}$ & Constant & $\begin{array}{l}\text { constant } \\
+ \text { trend }\end{array}$ & Constant & $\begin{array}{l}\text { Constant } \\
+ \text { trend }\end{array}$ & Constant & $\begin{array}{l}\text { constant }+ \\
\text { trend }\end{array}$ \\
\hline InGDPPC & 0.078 & -1.3969 & 0.00031 & -1.4553 & $-5.011 * * *$ & $-5.1121 * * *$ & $-5.011 * * *$ & $-5.1127 * * *$ \\
\hline COP & $-4.418 * * *$ & N/A & $-5.481 * * *$ & N/A & N/A & N/A & N/A & N/A \\
\hline InINT & -2.305 & N/A & -2.342 & N/A & $-5.357 * * *$ & N/A & $-5.357 * * *$ & N/A \\
\hline $\ln T O$ & -1.9713 & -2.731 & -1.7695 & -3.448 & $-4.8906 * * *$ & $-4.765 * * *$ & $-5.1716 * * *$ & $-4.878 * * *$ \\
\hline InGFCF & -0.473 & -3.2654 & -1.527 & -4.6794 & $-3.34 * *$ & $-4.6839 * * *$ & $-12.828 * * *$ & $-12.5696 * * *$ \\
\hline InFDI & -1.2173 & -3.579 & -1.2112 & -2.33 & $-5.4466 * * *$ & $-5.469 * * *$ & $-5.4850 * * *$ & $-5.772 * * *$ \\
\hline
\end{tabular}

The null hypothesis is that there is presence of unit root in the series.

$* * *, * *$, indicates the rejection of the null hypothesis of the existence of unit root at $1 \%$ and $5 \%$ significance level respectively. The lag length in the ADF test is based on the Akaike Information Criterion (AIC) 
Table 2 ARDL Bounds Test for Cointegration

\begin{tabular}{|l|l|l|l|l|l|l|l|}
\hline Critical Value Bounds & Value & \multicolumn{1}{|l|}{$\mathbf{1 0 \%}$ level } & \multicolumn{2}{|l|}{$\mathbf{5 \%}$ level } & \multicolumn{2}{l|}{ 1\% level } \\
\hline Intercept with trend & & $\mathrm{I}(0)$ & $\mathrm{I}(1)$ & $\mathrm{I}(0)$ & $\mathrm{I}(1)$ & $\mathrm{I}(0)$ & $\mathrm{I}(1)$ \\
\hline K (Number of regressors) & $\mathbf{5}$ & 2.75 & 3.79 & 3.12 & 4.25 & 3.93 & 5.23 \\
\hline F-Statistic & $\mathbf{7 . 2 2 7}$ & \multicolumn{5}{|l|}{} \\
\hline
\end{tabular}

$\mathbf{F}_{(\mathrm{GDPPC})}(\mathrm{LNGDPPC} \mid \mathrm{COP}$, LNINT, LNFDI, LNTO, LNGFCF)

Table 3 Estimated Long-run Coefficients Results

The Long-run Coefficient Results ARDL $(1,0,0,0,1,0)$

\begin{tabular}{|l|c|c|c|c|}
\hline Variable & Coefficient & Standard Error & T-statistic & P-Values \\
\hline $\boldsymbol{C O P}$ & -0.0032 & 0.0014 & -2.3271 & $0.0284^{* *}$ \\
\hline $\boldsymbol{L N I N T}$ & -1.0389 & 0.1995 & -5.2075 & $0.0000^{* * *}$ \\
\hline $\boldsymbol{L N F D I}$ & 0.0481 & 0.0547 & 0.8796 & 0.3875 \\
\hline $\boldsymbol{L N T \boldsymbol { O }}$ & 0.8955 & 0.1867 & 4.798 & $0.0001^{* * *}$ \\
\hline $\boldsymbol{L N G F C F}$ & 0.2945 & 0.0921 & 3.1971 & $0.0037^{* * *}$ \\
\hline
\end{tabular}

$* * *,(* *)$ denote significance at $1 \%$ and $5 \%$ respectively

Furthermore, the findings reveal the existence of positive and significant effect of trade openness and economic welfare, with a $1 \%$ increase trade openness resulting in an increase in GDP per capita by $0.8955 \%$. The Endogenous growth model (Grossman \& Helpman, 1991), and the Ricardian trade model (Dornbusch et al.,1977) are theories that reveal the improvement of economic growth on the account of increase in trade openness through the efficient allocation of resources, factor accumulation, technology transfer, and overabundance of knowledge. This outcome is also in line with empirical studies by Asiedu (2013) for Ghana and Keho (2017) for the Republic of Cote d'ivoire.

The paper also discovered that, there is a positive and significant relationship between gross fixed capital formation and economic welfare, evidenced by the increase in GDP per capita by $0.2945 \%$ when gross fixed capital formation increases by $1 \%$. Finally FDI has a positive, albeit insignificant relationship with economic welfare in the long run.

\subsection{Short-Run Dynamics and Error Correction Model}

Following the existence of a cointegration among the variables, the paper estimated the short run results and are displayed in Table 4. It is noted that the error correction term $\left(\mathrm{ECT}_{\mathrm{t}-1}\right)$ has negative and significant coefficient. This confirms the long-run association among the variables from the cointegration results. The coefficient of the errorcorrection term, $\mathrm{ECT}_{\mathrm{t}-1}$, which is -0.4858 means that at a speed of approximately $49 \%$, the error correction model corrects disequilibrium in its previous period, through the achievement of longrun convergence to equilibrium.

As indicated in Table 4, changes in crude oil price have a negative and statistically significant effect on economic welfare. That is, a unit percentage increase in crude oil price changes leads to a decline in GDP per capita by $0.0016 \%$. The shortrun results were consistent with the long-run results. The magnitude of impact in the short-run was however found to be less than the magnitude of the impact in the long-run.

Similarly, interest rate was found to have a negative and statistically significant association with economic welfare. This is explained by the decline in GDP per capita by $0.5 \%$ following a unit percentage appreciation in interest rate. The shortrun results were found to be harmonious with the long-run results. However, the magnitude of impact in the short-run was less than the impact in the long-run.

Trade openness also has positive and significant impact on economic welfare in the short run. This is evidenced by $0.96 \%$ and $0.43 \%$ increases in GDP per capita for current and lagged values respectively, following a unit percentage increase in trade openness. However, the magnitude of impact in the current short-run outcome was slightly greater than the impact in the long-run. The lagged short-run outcome was lower in impact compared to that of the long-run. 
Table 4 Estimated Short-run Error Correction Model (ECM)

\begin{tabular}{|c|c|c|c|c|}
\hline \multicolumn{5}{|c|}{ Dependent Variable: LNGDPPC, ARDL $(1,0,0,0,1,0)$} \\
\hline Variable & Coefficient & Standard Error & T-statistic & P-Values \\
\hline$\triangle C O P$ & -0.0016 & 0.0071 & -2.2132 & $0.0362 * *$ \\
\hline$\Delta \operatorname{lnINT}$ & -0.5047 & 0.1170 & -4.3128 & $0.0002 * * *$ \\
\hline$\Delta \ln F D I$ & 0.0234 & 0.0273 & 0.8562 & 0.4000 \\
\hline$\Delta \ln T O$ & 0.9633 & 0.1595 & 6.0391 & $0.0000 * * *$ \\
\hline$\Delta \ln T O(-1)$ & 0.4351 & 0.1239 & 3.5113 & $0.0017 * * *$ \\
\hline$\triangle \ln G F C F$ & 0.1431 & 0.0439 & 3.2569 & $0.0032 * * *$ \\
\hline CointEq (-1) & -0.4858 & 0.0794 & -6.1172 & $0.0000 * * *$ \\
\hline
\end{tabular}

R-Squared

Adjusted R-Squared

Durbin Watson Statistic

Prob (F-statistic)

Akaike Information Criterion
77.07

74.77

1.97

0.00

$-1.86$

$* * *, * *$ denote significance at $1 \%$ and $5 \%$ respectively

Gross fixed capital formation is positive and significantly affect welfare in the short-run. Thus, a unit percentage appreciation in gross fixed capital formation is associated with $0.14 \%$ increase in GDP per capita. However, the magnitude of impact in the short-run outcome was less than the impact in the long-run. Finally, foreign direct investment within the period of study has a positive, but insignificant relationship with economic welfare in the short-run. This outcome does not deviate from the outcome in the long-run in terms of direction and insignificance.

\subsection{Impulse Response Function of Economic Welfare to Crude Oil Price Changes}

The impulse response function provides the opportunity to measure the sensitivity of the economic welfare variable in a vector autoregressive model to one standard deviation (SD) shock in the rate of change in oil price variable. The impulse response in this study was restricted to the confines of a ten-year horizon. The horizontal axis in the graph indicates the number of years preceding the initialization of the impulse, whereas the vertical axis shows the response of the economic welfare variable. The impulse response of Ghana's economic welfare to oil price changes was estimated as shown in Fig. 1. This response function lies within the $95 \%$ confidence intervals, which is desirable. The outcome generally reveals a marginal stability in the long-run, confirming the weakening effect of changes of crude oil price on GDP per capita at the end of the 10-year horizon.



Fig. 1 Impulse response of economic welfare to crude oil Price changes in Ghana

\subsection{Model Diagnostics and Stability Tests}

The variability of estimated parameters of a time series data over time is econometrically inevitable. Table 5 shows a summary of model diagnostics and goodness of fit. The Durbin Watson statistic was 1.96, showing the nonexistence of serial correlation in the model. This was further crosschecked with the Breusch Godfrey test to get an affirmation of the absence of serial correlation. With the p-value of 0.9340 (> 5\%), the null hypothesis of no serial correlation was accepted. The model also passed the Ramsey RESET test for model specification with the acceptance of the null hypothesis of no omitted variables with a p-value of $0.5155(>5 \%)$. The null hypothesis of homoscedasticity was accepted following the realisation of a greater than $5 \%$ p-value (0.6594) in the Breusch-Pagan-Godfrey test for heteroscedasticity. The Jacque Bera test 
statistic also showed that the residuals were normally distributed.

Table 5 Post estimation Model Diagnostics

\begin{tabular}{|l|l|}
\hline Diagnostics & Outcome \\
\hline R-Squared & 0.770657 \\
\hline Standard Error of Regression & 0.090301 \\
\hline Akaike Information Criterion & -1.861203 \\
\hline Durbin Watson Statistic & 1.964716 \\
\hline $\begin{array}{l}\text { Breusch Godfrey (Serial } \\
\text { Correlation) LM }\end{array}$ & $0.0070[0.9340]$ \\
\hline $\begin{array}{l}\text { Breusch - Pagan-Godfrey Test } \\
\text { (Heteroscedasticity) }\end{array}$ & $0.7359[0.6594]$ \\
\hline Normality & $0.6359[0.7277]$ \\
\hline $\begin{array}{l}\text { Functional Form (Ramsey } \\
\text { RESET) }\end{array}$ & $0.4356[0.5155]$ \\
\hline p-value in parenthesis & \\
\hline
\end{tabular}

Finally, the coefficients of the model are analysed for stability using the Cumulative Sum of Recursive Residuals (CUSUM) and Cumulative Sum of Squares of Recursive Residual (CUSUMSQ) tests proposed by Pesaran and Pesaran (1997). According to Figs. 2 and 3, all the coefficients of the estimated model fall within the $5 \%$ critical bounds, thus confirming the stability of the model.

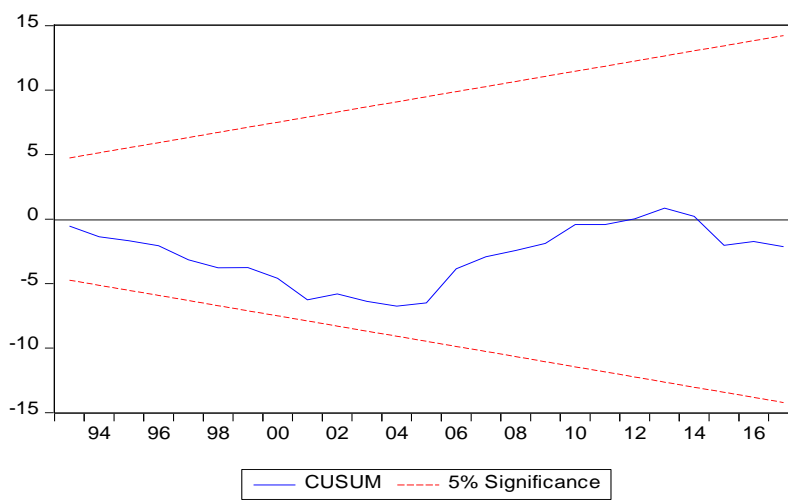

Fig. 2 Cumulative Sum of Recursive Residual Graph

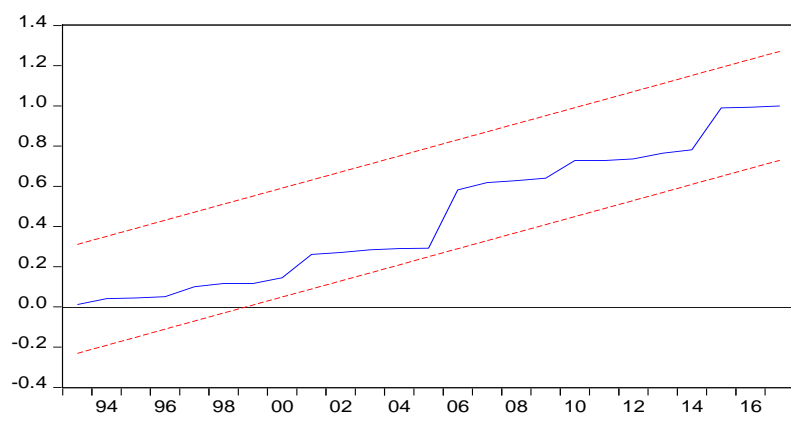

Fig. 3 Cumulative Sum of Squares Recursive Residual Graph

\section{Conclusion and Recommendations}

This paper sought to explore the impact of crude oil price changes on economic welfare in Ghana using an annual data spanning 1983 - 2017. The paper employed the Autoregressive distributed lag (ARDL) estimation technique and the findings revealed that crude oil price changes have a negative and significant effect on economic welfare both in the long and short run, albeit marginal. In terms of the covariates, the findings also revealed that in both long and short run, trade openness and gross fixed capital formation have positive effect on economic welfare. Interest rate however, has a negative effect on economic welfare not only in the long-run, but in the short-run as well, whereas foreign direct investment has a positive effect, albeit insignificant effect.

Based on the outcome of the paper, it has been established that there is a notable influence of crude oil price changes on economic welfare, even though the impact was found to be marginal. It is recommended that policy makers implement policies aimed at influencing economic welfare in Ghana with some level of consideration for crude oil price changes. Since Ghana exports crude oil, but imports petroleum products that are more expensive and have direct link with global crude oil prices, the paper recommends the hedging of the prices of crude oil imports as part of a risk management strategy to reduce the volatility associated with crude oil price changes. Furthermore, the paper recommends reduction of the Special Petroleum Tax. Finally, the paper recommends the introduction of less expensive alternative sources of energy that are also renewable in order to reduce crude oil price vulnerability of Ghana's economy and improve upon economic welfare.

\section{References}

Al Sabah, K. J., Palliam R., and Al Salem. A. (2016), "Sustaining standard of living amidst volatile oil prices- lessons from the gulf countries", Consilience: The Journal of Sustainable Development, 15(1), pp.101-118.

Anon. (2014), Centre for Study of Africa Economies (CSAE), "Crude oil price and economic growth: The case of Ghana", https://editorialexpress.com/cgiin/conference/download.cgi?db_name $=$ CSAE2014\&paper_id =165. Accessed: February 23, 2020

Anon. (2018), Energy Commission of Ghana,

"Ghana Energy statistics", http://www.energycom.gov.gh/files/2018\%20Ke y\%20Energy\%20Statistics.pdf. Accessed:

March 2, 2020 
Asiedu, K. (2013), "Trade liberalization and growth: the Ghanaian experience", Journal of Economics and Sustainable Development, 4(5), pp. $125-135$.

Awunyo -Vitor, D., Samanhyia, S., and Bonney, A. E. (2018), "Do oil prices influence economic growth in Ghana? An empirical analysis", Cogent Economics \& Finance, 6(1), pp. 1-14.

Ajayi, A. S., Oladepo, O, A., Ajayi, L. B., and Nwanji, I. T. (2017), "Interest rate and economic growth: the case of Nigeria", International Review of Business Research Papers, 13(1), pp. 141-150.

Bouri E. (2015), "Return and volatility linkages between oil prices and the Lebanese stock market in crisis periods", Energy, 89(9), pp. 365-371.

Cantah, W. G.,and Asmah E. E. (2015), "Crude oil price and growth of output: the case of Ghana", International Journal of Economics, Commerce and Management, 3(5), pp. $470-498$

Dogah, K. E. (2015), "The impact of Oil price shocks on the macroeconomy of Ghana", Journal of Poverty, Investment and Development, 9, pp. 37-54.

Dornbusch, R., Samuelson, A.P., Dornbusch, R., and Fischer, S. (1977), "Comparative advantage, trade, and payments in a Ricardian model with a continuum of goods", American Economic Review, 67(5), pp. 823-839.

Glewwe, D. (1991), "Investigating the determinants of household welfare in Cote d'Ivoire" Journal of Development Economics, 35(2), pp. 307 - 337.

Grossman, G., and Helpman. E.(1991), "Trade, knowledge spillovers and growth", European Economic Review, 35(2-3), pp. 517-526.

Keho. Y. (2017), "The impact of trade openness on economic growth: The case of Cote d'Ivoire", Cogent Economics \& Finance, 5(1), pp. 1 - 14. DOI:10.1080/23322039.2017.1332820.

Olukayode, M. E., Adetayo, A.S., and Oyelade, A.O. (2018), "Impact of petroleum product price on human welfare in Nigeria", http://dx.doi.org/10.23856/2903.

Accessed: March 19, 2019.

Pesaran, M.H., and Pesaran, B. (1997), Working with Microfit 4.0: Interactive Econometric Analysis, Oxford University Press, Oxford, 515 pp.

Sanchez, M. V. (2011), "Welfare effects of rising oil prices in oil-importing developing countries", Developing Economies, 49(3), pp. 321-346.

Wang, Y. (2013), "Oil price effects on personal consumption expenditures", Energy Economics, 36, pp. 198-204.

\section{Authors}



K. Kamasa is an Economist and Lecturer at the University of Mines and Technology, Tarkwa, Ghana. He holds both $\mathrm{PhD}$ and MPhil degrees in Economics from the Kwame Nkrumah University of Science and Technology, Kumasi, Ghana. His research areas include Macroeconomics, Financial and Monetary Economics, International Finance and Trade, Public Finance, Economic Growth and Resource Economics.

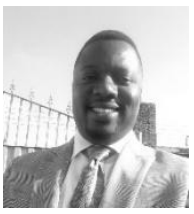

D. B. Amponsah is a Professional Engineer (PE GhIE) who works as a Senior Plant Metallurgist at Anglogold Ashanti, Iduapriem Limited, Tarkwa. He holds MPhil degree in Industrial Finance and Investment from Kwame Nkrumah University of Science and Technology, Kumasi, Ghana. His research areas include Mineral Economics, Corporate Finance, Energy Economics and Natural Resource Economics.

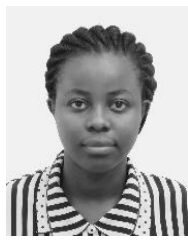

P. Forson is a graduate research student pursuing MPhil Economics at the Kwame Nkrumah University of Science and Technology, Kumasi, Ghana. Her research areas include Energy Economics, International Trade and Finance as well as Monetary Economics. 